\title{
آلية الإيحاء في رسوم بول غوغان
}

\section{م. م لؤي رهيم داود \\ كاية الفنون الجميلة / جامعة القادسلية \\ خلاصة البمث}

للرسم الاوربي الحديث معايير ومفـاهيم متعددة ابتدأت معالمها مع الانطباعية في تجسيد اللحظة واغفـال الخط ومعايير البنـاء

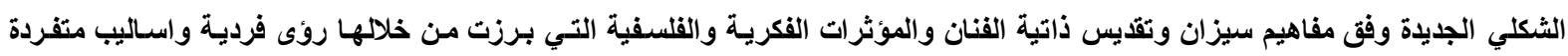
اصبحت لها الاثر الفاعل في رسم الحداثة ، وفي بحثنا الموسوم (آلية الايحاء في رسوم بول غوغان ) نسعى لكثف الاستراتيجيات والمعايير

التي اسس لها الفنان بول غوغان لأظهار المعنى الباطن والكامن وتأثيره في البنـاء الثكلي لتحقيق فكرة العدل والاختزالات الثكلية التي

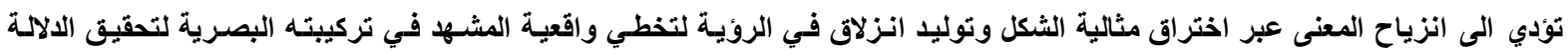

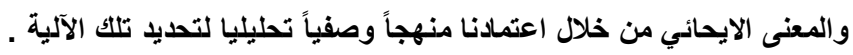
في الفصل الاول قام الباحث بتحديد مشكلة البحث وتحديد أهميته والمنهج المتبع وتحديد مفهوم الايحاء بما يتوافق ومفـاهيم الرسم الحديث وبما يحقى غاية البحث ـ وفي الفصل الثاني وفي مبحثه الاول تم توضيح ماهية الايحاء ما بين المعنى والمفهوم ، امسا المبحث الثاني فتم تحقيق مدخل لتحدي مفاهيم الرسم الاوربي الحديث وتطرق المبحث الثالث لمفهوم الرمزية في الرسم الحديث بوصفها احد المرتكزات التي ولي قام عليها بأثر مرجعيات الفنان والتي من خلالها تتضح لنا خصوصيته الذاتية ورويته الفنية. وفي الفصل الثالث قام الباحث بتحليل (بالث) ثلاث

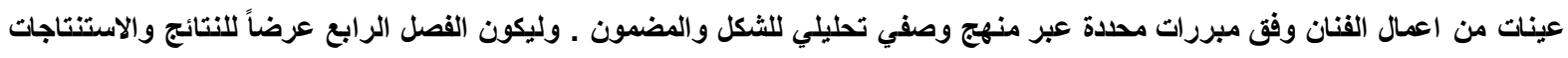

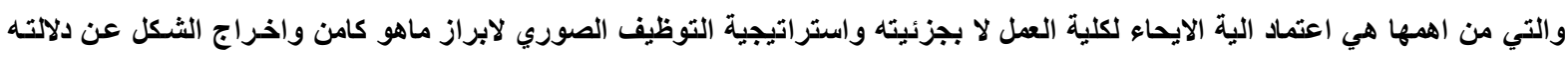

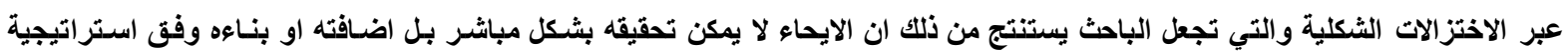

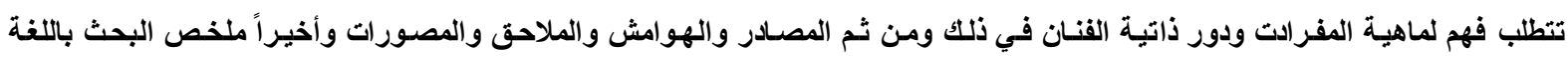
الانكليزية.

\section{Abstract}

The present paper is concerned with the mechanisms of evocation in the paintings of Paul Gogan . It aims to investigate the artistic strategies and norms that Gogan established and on which he based his work . These invocative effects are of prime importance in deciding the meaning of the work. These strategies give his work powerful, and influential invocative effect which is of prime importance in deciding the meaning of the work. The researcher adopted an analytical approach to investigate the mechanisms of invocation in Gogan's work . The paper falls into five chapters. The first chapter puts forth the problem of the research, its significance, the approach followed, and a definition of the concept of invocation, according to modern painting. The second chapter presents invocation between concept and meaning, the approaches of modern European painting, symbolism as a basic component of this art, and the major sources of the major sources of Gogan's artistic experience and vision of life . In the third chapter, three sample works of the painter under study are analyzed in terms of shape and content . Chapter four sums up the results of the study and a discussion of them . The most important of them is depend on Suggestion with the totality of the work not dividing it and strategy of fake function to appear what invisible and appear the shape of it across formal abbreviation which make the researcher conclude from that suggestion can't achieve it directly but we can add it or construction it according to the strategy requires understanding what are the items and the role of artist in his matter .and footnotes, appendixes, charts and the abstract in English .

- الفصمل الاول

ا . مشكلة البحث: تتمثل مشكلة البحث بدر اسـة آليـة الايحساء في رسوم بـول غوغان وفق مفـاهيم الرسم الاوربي الحديث ومعـييره عبر الرمزيـة التي حمل مفاهيمها وعمل بها ومحاولته المستمرة للخروج من التقليديـة للبحث عن مـاهو كـامن 
وجو هري ومن ثم فأن مشكلة فهم الايحساء هي من الامور المعقدة التي تحتاج لادر اك الاستر اتيجيات التي تنم بها عبر

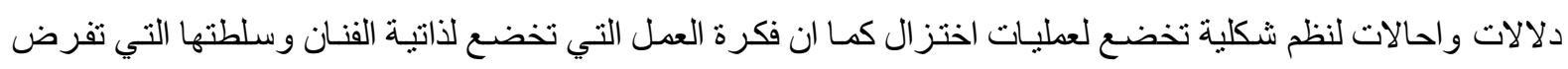

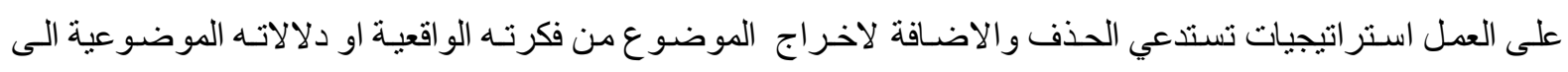
مفاهيم باطنة تظهر على سطح العمل الفني الذي يتطلب استر اتيجيات احالة تحقق هدفها بتوظيف مفردات العمل الفني مابين الو اقع وفكرة الفنان لتحقيق الايحاء وفق فكرة الفنان ، لذا فـان مشكلة البحث تكمن في فهم ماهية المعنى الايحائي

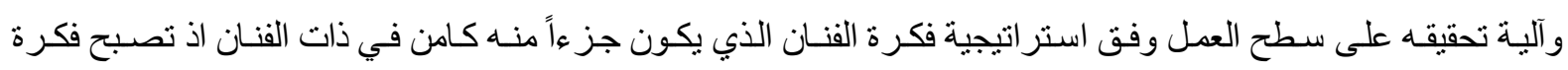

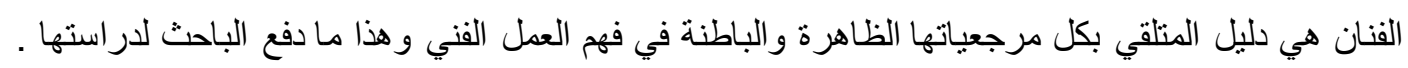
r. اهمية البحث والحاجة اليه: تنبع اهمية البحث من الحاجة الملحة لدراسة الرسم الاوربي الحديث من خـلال فهم التنوع

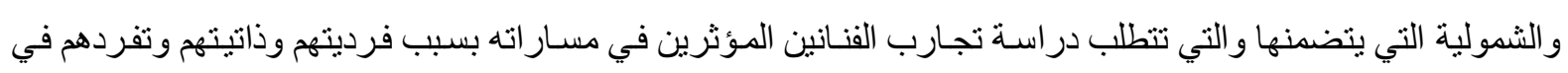

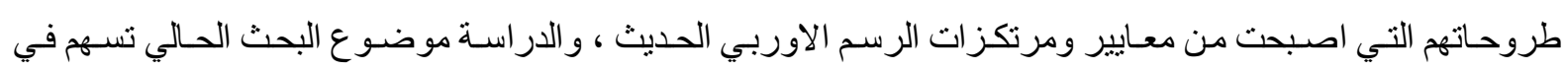

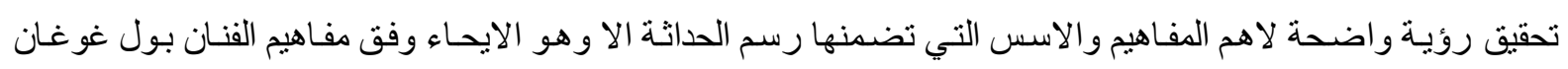

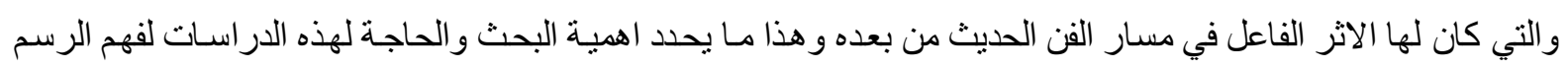
الاوربي الحديث . r. هدفا البحث : يهدف البحث الى :

أ- تحقيق رؤية واضحة لفهم الآليات التي يتحقق بها مفهوم الايحاء في رسوم بول غوغان

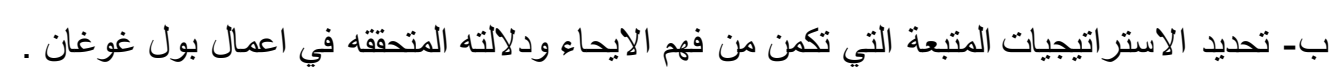

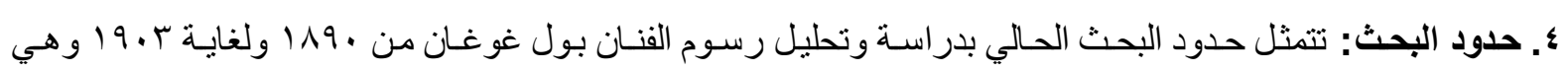

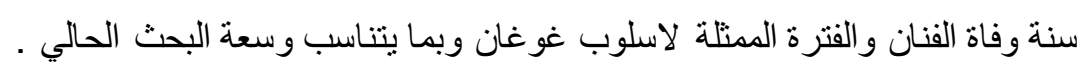
ه. تحديد المصطلحات: آلية: ((ب. مجازاً ، كل مسـار يمكن فيه بالتحليل، تحديد سلسلة مر احل متر ابطة وملحقة بعضهها

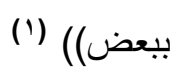

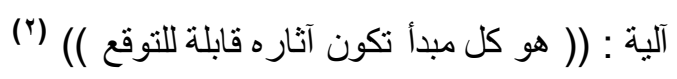

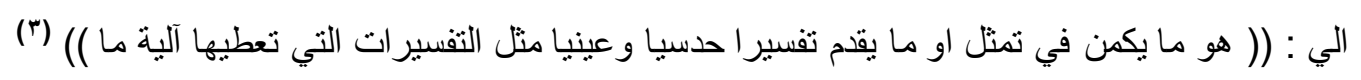

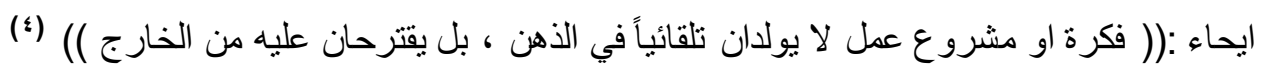

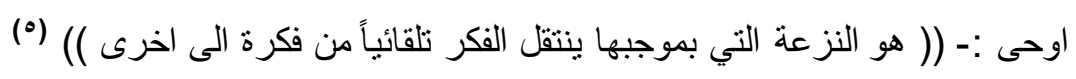

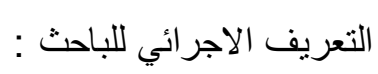

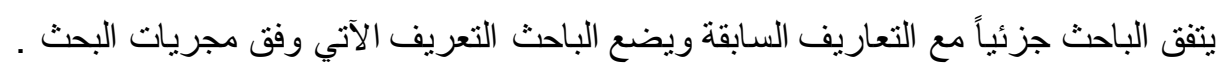

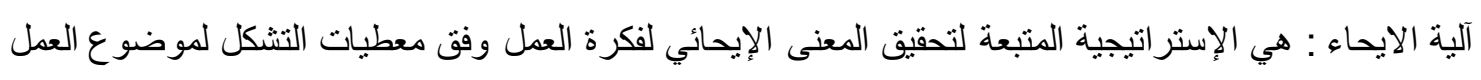

\section{الفصل الثاني- الاطار النظري والدراسات السابقة}

المبــث الاول، الايهاء بـيز المعنسى والمفهوم

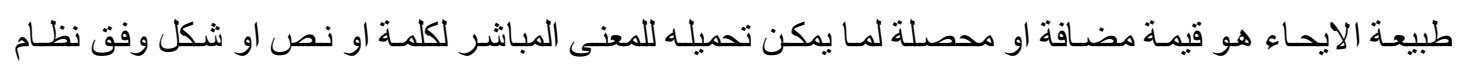

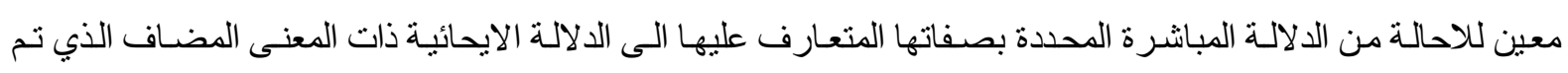
بناؤه ، فعندما تكون مجموعة من الاشكال او المفردات موحية بموضو لمعن معين يكون ذلك بتحميل الاشكال المعنى الز ائد 
عن المعنى المباشر المحدد عبر الخصـائص التي ترتبط بتلك الاشكال او المفردات ، وبمـا يحقق فهما بالاحالة من المعنى

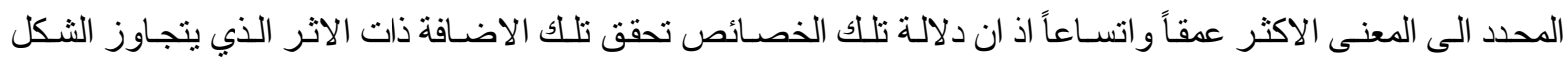
نفسـه بقيمتهـ الحسية والعقليـة ، بـأثر اسباغ ذاتيـة معينـة على مجموعـة من العناصـر او الاشكال ببعدها الفيزيقي لتحميل

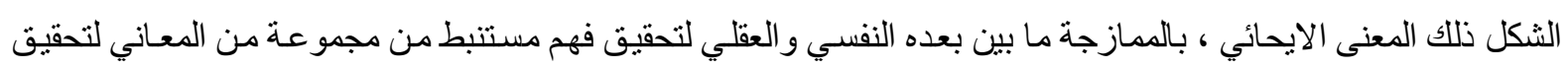

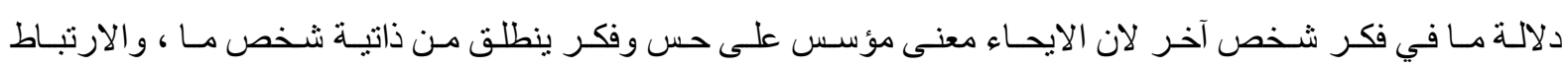

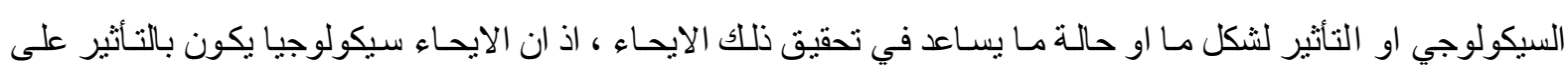
سلوك شخص ما بطريقة المؤثر والاستجابة التي قد تكون كامنة فيه والايحاء (( حسب تعريف هيلمسلف Helmslev ، معنى ثان بنى دالة بواسطة سلسلة من الدلالات المحددة سـابقاً )( (") و التحديد هنـا هو تعيين لدلالة المعنى المحدد المتعاقد عليه وفق البناء الذهني لـه كمدرك بصري او معنى لغوي ، و العقل او الذات المنظمـة لذلك المؤثر وفق استر اتيجية معينة

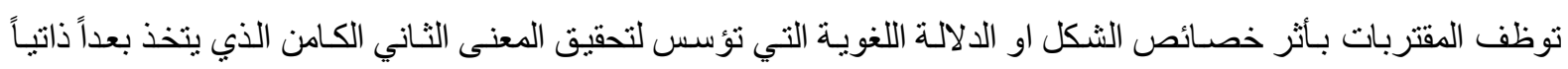

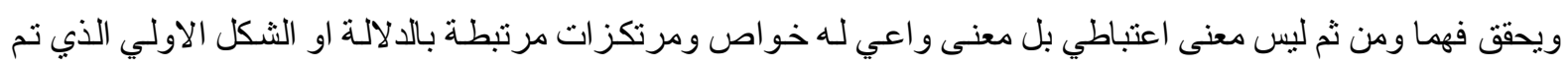

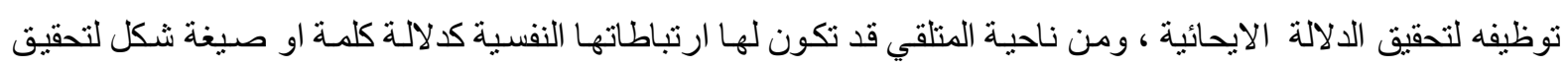

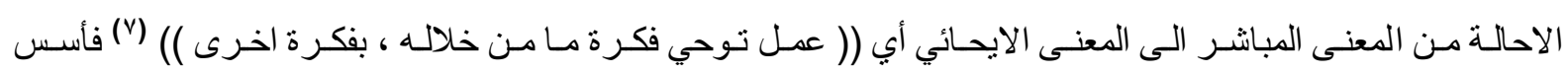

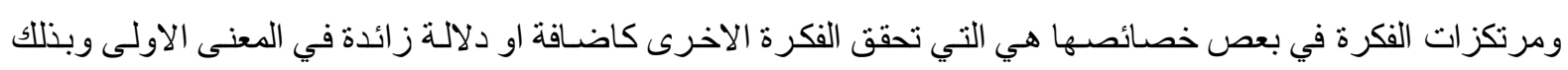
يتحقق الايحاء بمعزل عن المعنى الاولي ولكن كنتيجة تتم عبره .

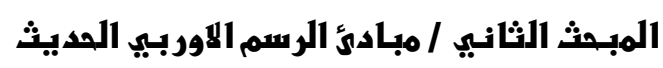

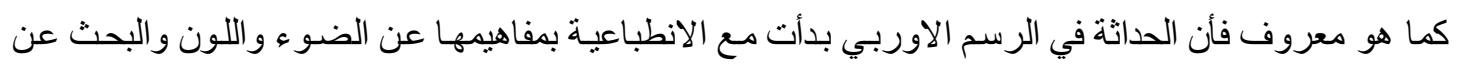

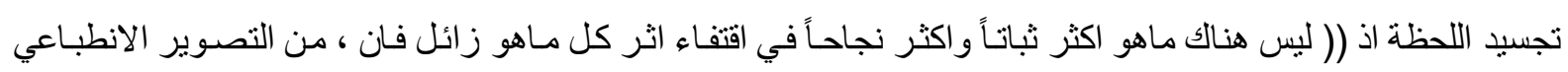

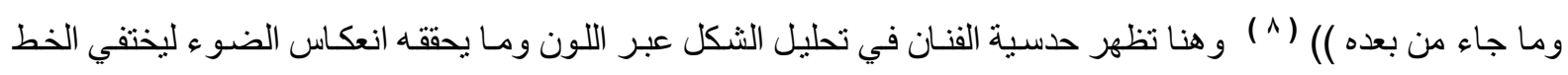
ويضمر المضمون ليتم تجاوز الموضوع وتظهر النزعة الجمالية اذ اخذت (( الرؤية الانطباعيـة تحول الطبيعة الى عملية نمو و انحلال ) (9) و التي عملت على تحقيق منفذ لتجسيد رؤيـة الفنان الذاتية التي اصبحت مبدأ مهمـا في رسم الحداثتة ينت

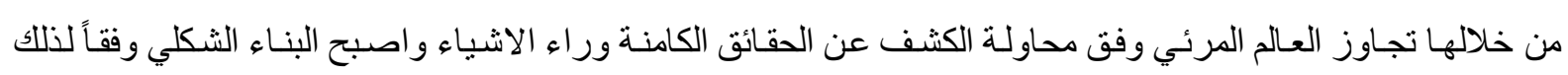

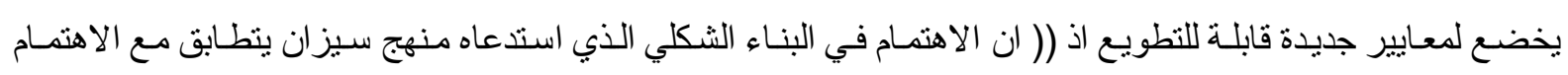

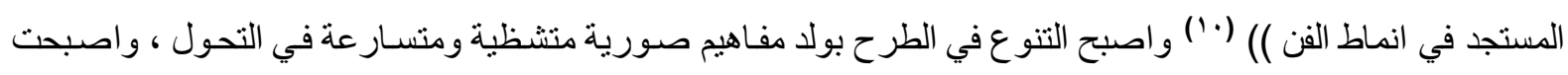
التلقائية واللاعقلانية تبيح للفنان الخوض في غمـار تجارب تقود الى تجاوز الخبرة المرئية واخر اج الاشكال عن شيئيتها

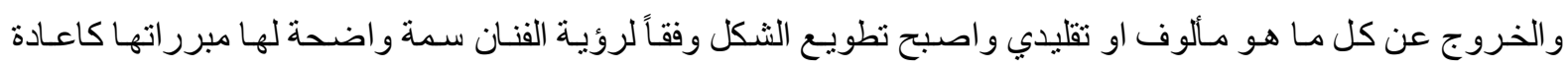

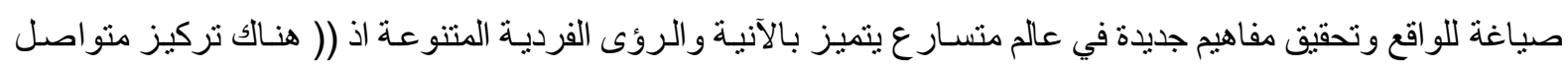

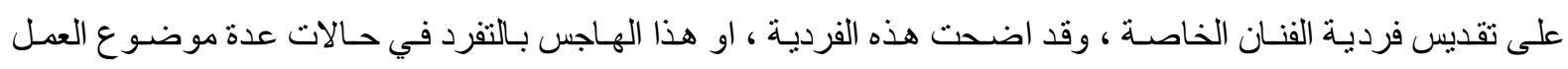

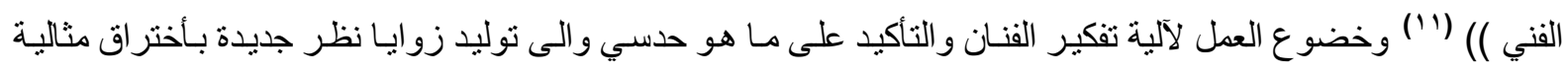

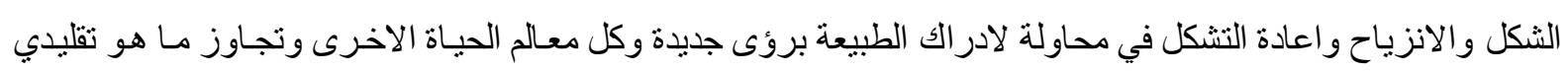

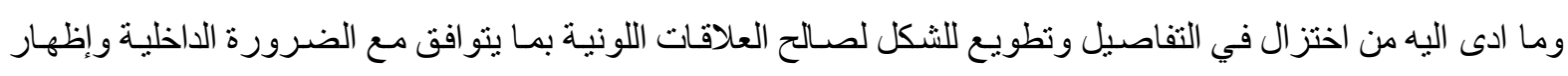
ما هو كامن وغامض وما يحلث من تفاعلات بين هو اجس الفنـان والو اقع عبر ذاتيته او معالجـة ديناميكيـة الحياة و البحث

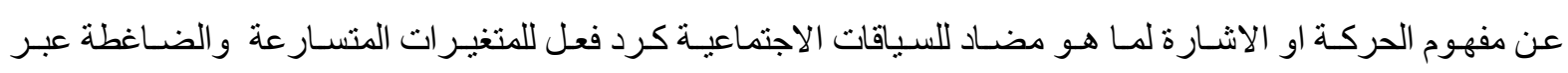


معايير لا واعية او عبثية او بأثر التحليل النفسي عبر سلطة الفكر الحر بين الوعي واللاوعي والمعقول واللا معقول او

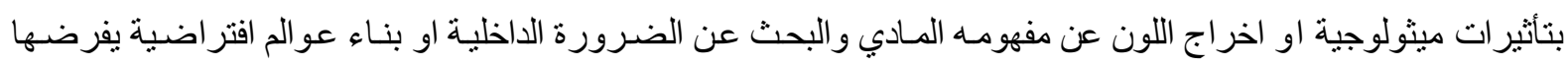

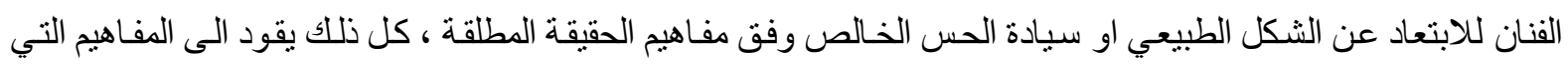

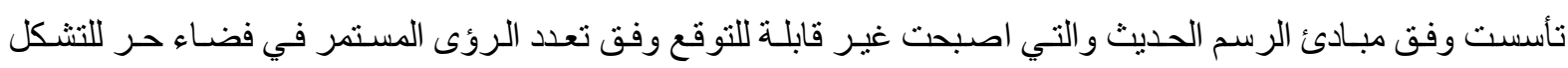
والتلاقح الفكري بنظام نوليدي مستمر .

\section{الهبــث الثالث / الرمزية في الرسم العديث}

برغم ان الرمزيـة ظهرت بعد الانطباعيـة ولكن لها جذور سبقتهاو هي تتجـاوز الوصفية كففهوم كونها تقوم

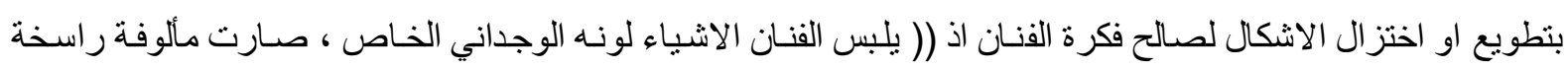

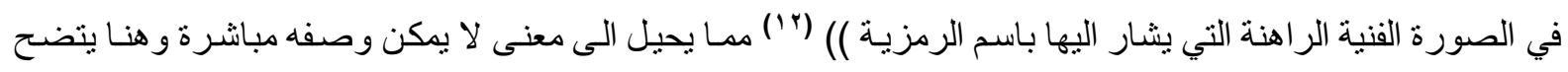

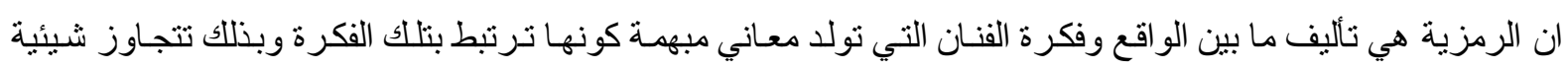

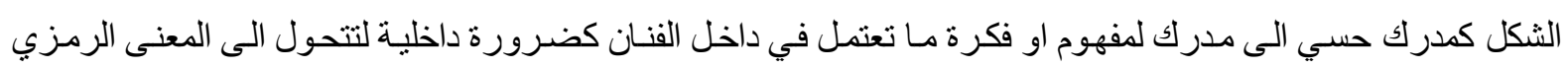

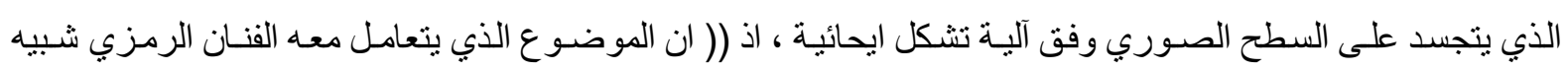

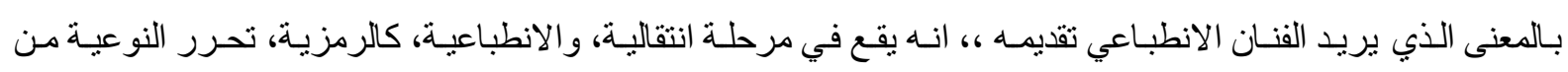

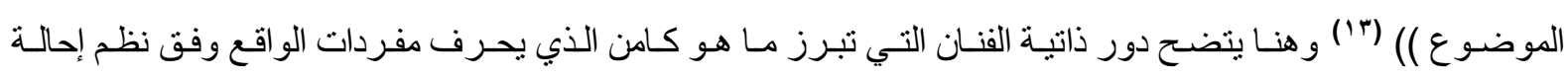
وعملية تشكل تتجاوز المألوف وتتسم بالتأليف من خـلال فكرة الفنان الذي يجعل من الاشكال والصور وسيط لتحقيق قيم

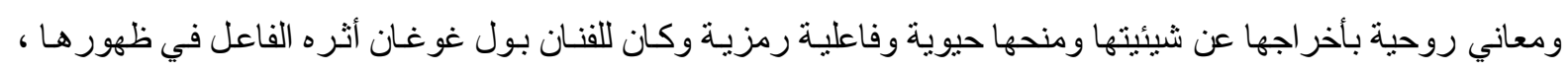
وحين التقى عام •1199 بعدد من النقاد و الرسامين مثل مالارميـه وريدون ومونغريد أصبحت اعمالـه تمثل معايير ومفاهيم الرمزية التي تتمثل بـامتلاك العمل لفكرة والتي من خلالها تكون رمزيته وان يكون ذاتيـاً من خـلال كونـه تزيينيا توليفيا

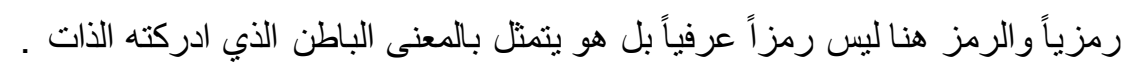

\section{المبـث الرابـر : مرجعيات الفنان بول غوغان}

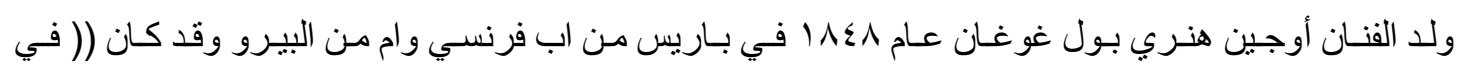

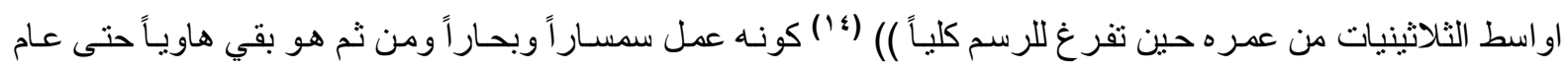

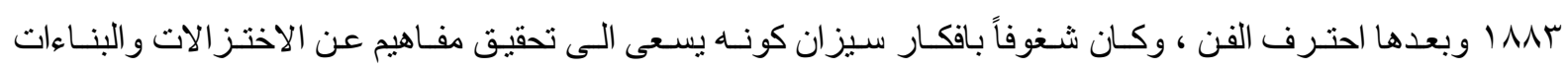

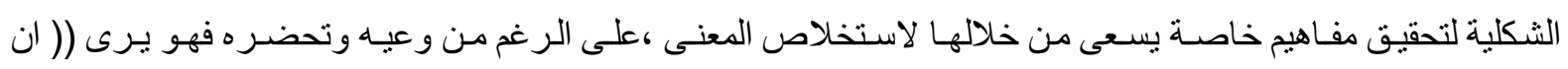

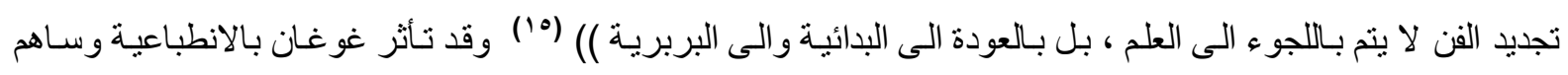

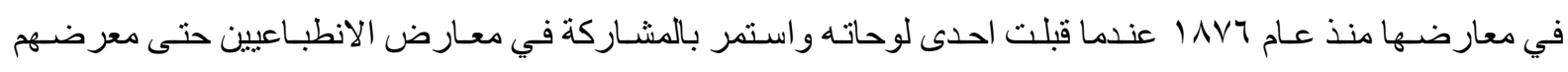

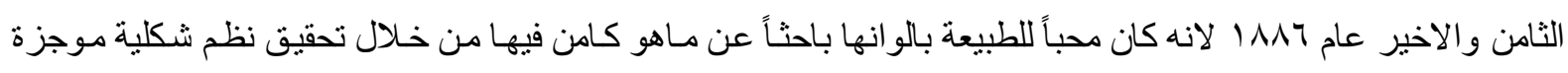

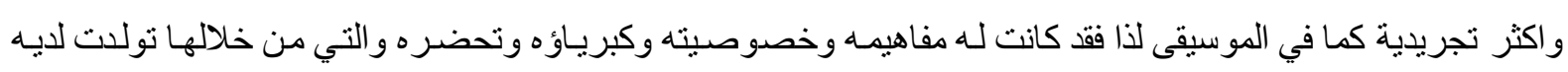

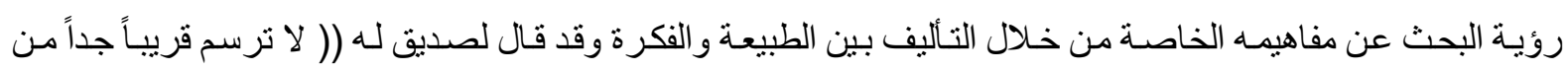

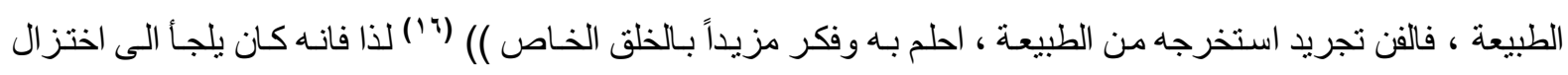
الاشكال وتحريفها وتغيير الو انها وفق وعبه وفكره الخاص بطبيعة اسلوب لم تتضح سماته الا بعد مرور فترة من التقويم

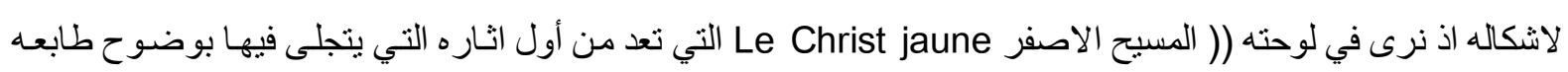
الخاص فيما يتعلق بتبسبط الاشكال وتسطيحها وابراز حدودها الخارجيـة )) (v') وهو في هذه المرحله كـان يهنم بمزايـا 
تكوين الثكل وخصوصيته التي تحمل تأثثرات فنون الثرق و التي تأثر بها الكثير من الفنانين ومن ثم أتخذ منـه صيغة اخرى اكثر وضوحاً في وحدته الأسلوبية وغوغـان كان يسعى بطبيعته للتحرر من الطبيعة ومن قيودهـا لتحقيق رؤيـة

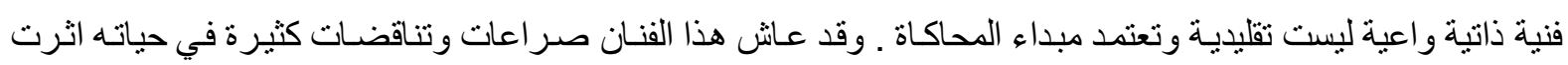

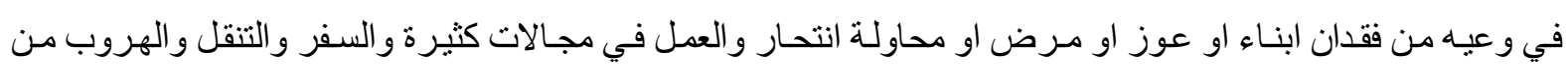

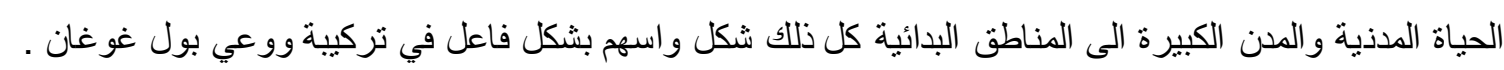
مؤشرات الاطار النظظري : يحدد الباحث اهم النقاط التي اسفر عنها الاطار النظري بما يلي

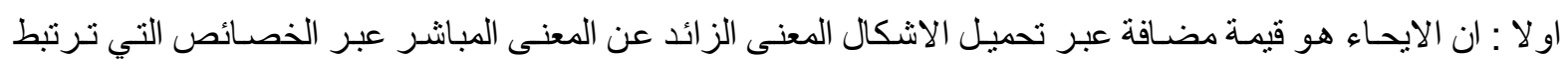
بتلك الاشكال ثانيا : المعنى الايحائي هو اسباغ لذاتيـة الفنـان على مجموعة من العناصر والاشكال ببعدها الفيزيقي بالممازجة مـا بين

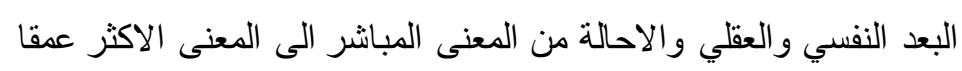
ثالثا : للإيحاء تأثير سيكولوجي على سلوك الثخص بطريقة المؤثر و الاستجابة رابعا : الفن الحديث ادى الى زوايـا نظر جديدة بـاختراق مثالية الثكل واعادة التشكل في محاولـة لادر اك الطبيعة برؤى جذيدة

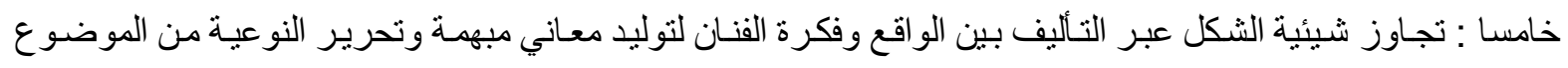

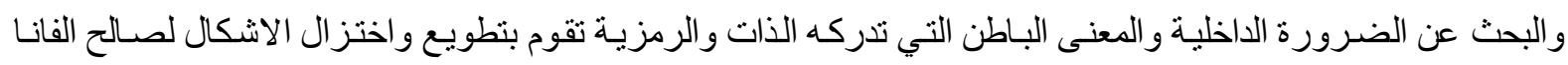
عبر ذلك

\section{الدراسات السابققة :}

لا نوجد دراسات سابقة تبحث في آلية الايحاء في اعمال الفنان بول غوغان حسب علم الباحث

الفصل الثالث : اجراءات البمث

ا ـ في هذا الفصل سيتم تحديد الاجراءات المتمثلة في تحديد مجتمع البحث والعينة القصدية من رسوم الفنان بول غوغان أـ قام الباحث بتحديد مجتمع البحث ممثناً بالاعمـال الفنبـة المنشورة و المعروفة و الموثقة التي قـام الفنان برسمها منذ عام

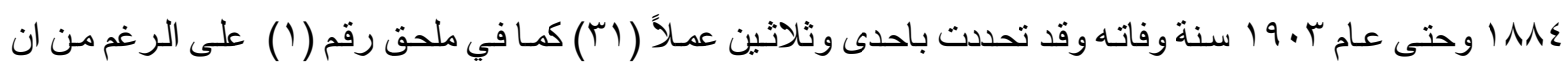
الفنان كان لايه عدد كبير من الاعمال الفنية ب- مبررات اختبار العينة القصدية . لقد تم اختيار العينات وفق المبررات الاتية :-

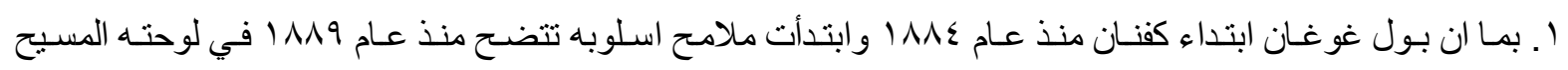
الاصفر وفقا لمعطيات الاطسار النظري واخذت وحدته الاسلوبية تتخذ ملامحها بشكل واضح بعد عام •119. ـ فسيعتمد الباحث الاعمال الفنية بعد تلك الفترة بوصفها عينة قصدية . r. اعتماد الاعمال الاكثر حضور اً وتأثير أ كعينات قصدية 


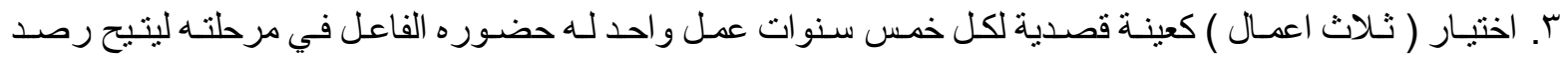

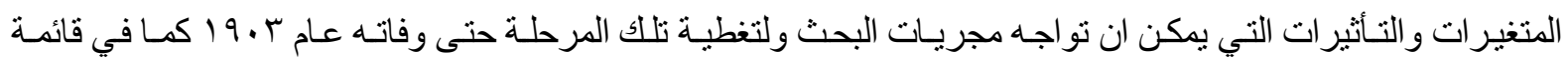

الاشكال

ج منهج البحث: يعتمد الباحث المنهج الوصفي التحليلي عبر اختيار عينـات قصدية من اعمال الفنـان بول غوغان بمـا

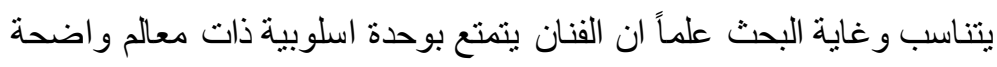

د- طريقة التحليل بعتمد الباحث المنهج الوصفي التحليلي في تحليل عينة البحث وفق معطيات الاطار النظري هـ أداة التحليل : (n) اعتمد الباحث على المعطيات التي اسفر عنها الاطار النظري في تحليل عينة البحث . التحليل

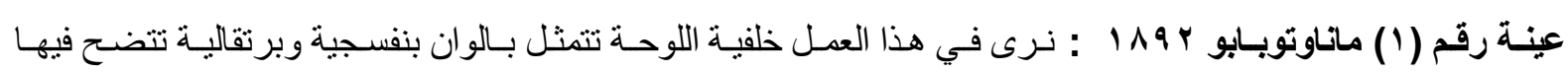
ضربات الفرشاة وبخطوط افقية بسيطة في اعلى منتصف اللوحة زهرة بلون ابيض وهي ليلية اسفلها في الجز ء الاخير

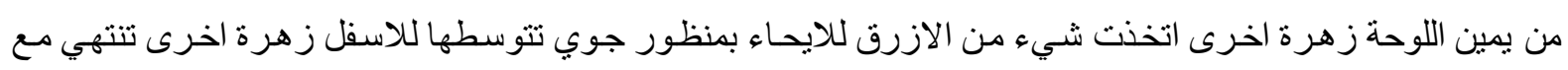

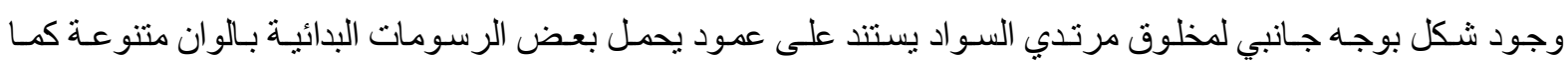

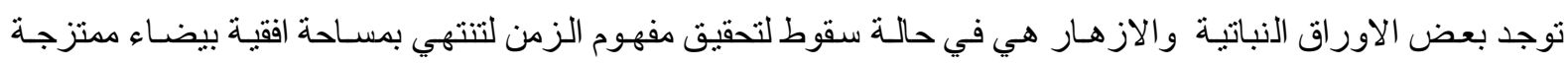

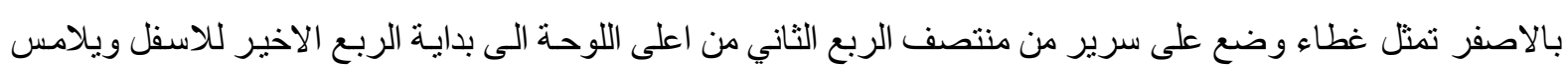

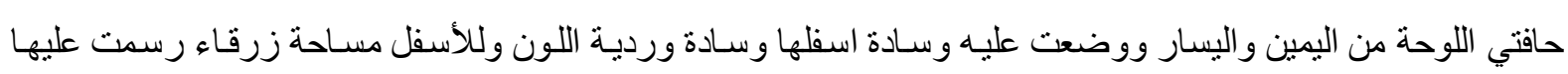

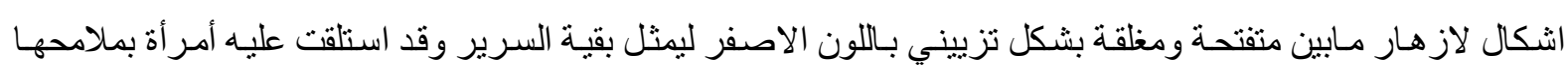

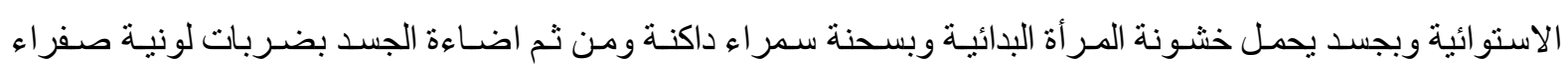
وبرتقاليـة لأظهار تفصيلات الجسد وقد سـاهت ارضية الفر اش بلونها الفاتح بـأبراز قيمة الجسـ وتمييزه ه ، وقد ادارت المر أة رأسها بأتجاه مقدمة اللوحة وقد افربت شعر ها ووضعت كفها اليمين عليه ، الابهام على الفم وثنلاث اصـابع ملتصقة

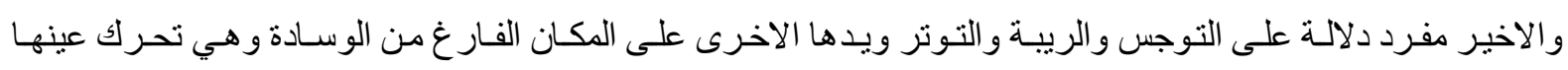

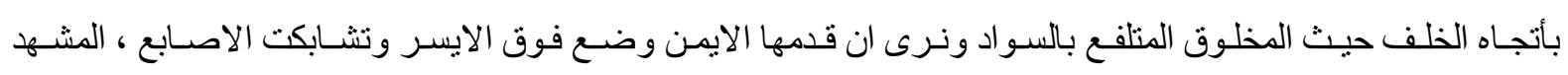

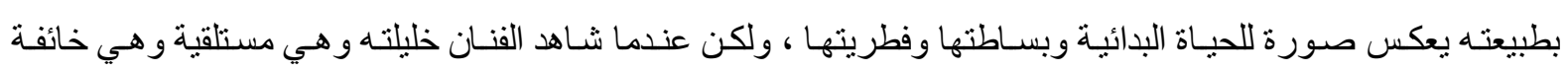

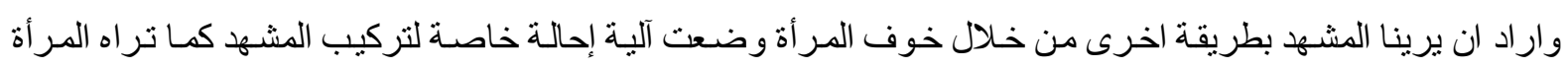

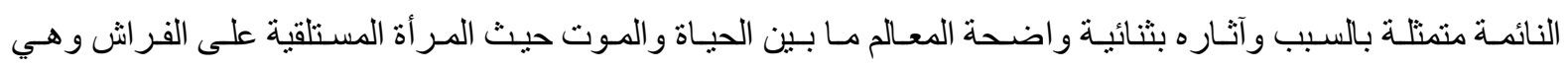
المفردة الرئيسية في العمل اذ نرى دلالـة الخوف على وجـه المر أة و الكف اليسرى على الوسـادة على عدم وجود خليلهـا

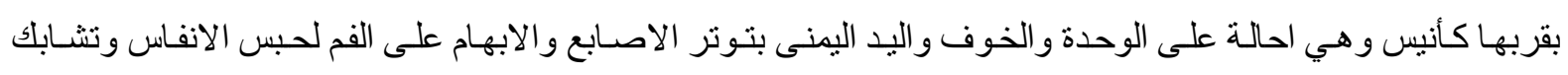

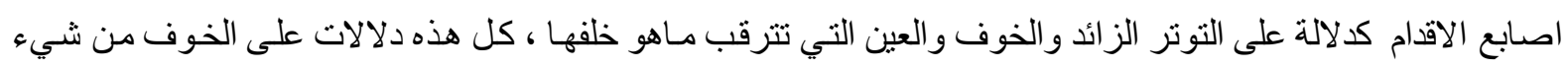

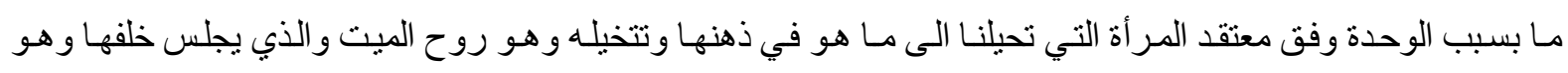

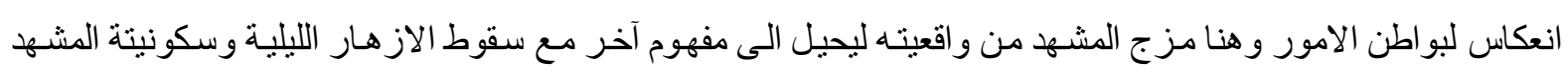

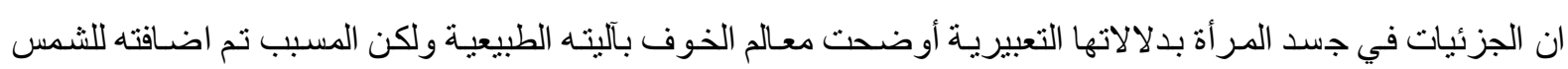


و هو اصـلاً قـابع في ذهـن الهـر أة ، وبذللك فـأن الاحسالات الجزئيسة وفق معايير هـا الطبيعيـة تم توظيفهـا لتحيل الى مفهوم الخوف من الموت وروح الميت وهذا المفهوم تم تحقيقه من خـلال الاستراتيجية التي اتبعها الفنـان لمعرفته بالبيئة البدائية و التفكير البدائي ومعتقداته ليجعل مـا هو كامن بطغى على المشهد بطريقة توازي بدائيته وقد كتب الفنان في اعلى يسار

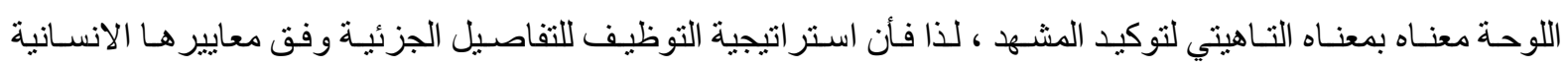

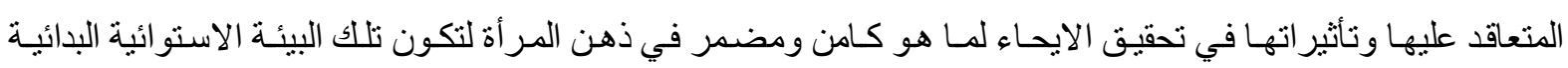

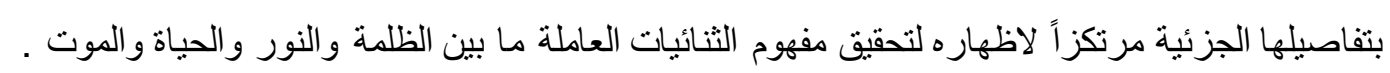

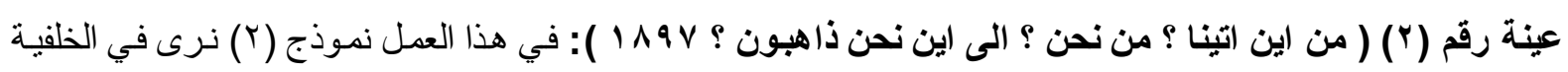

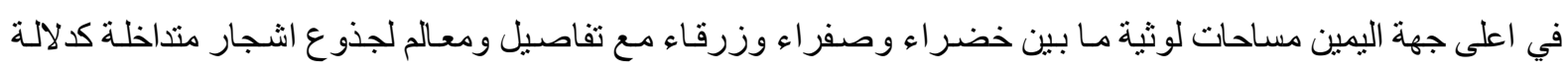

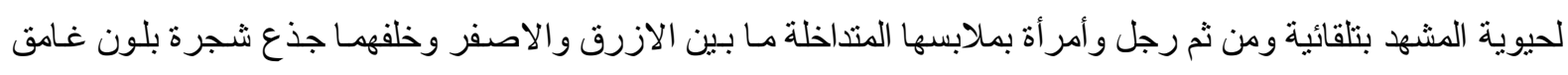

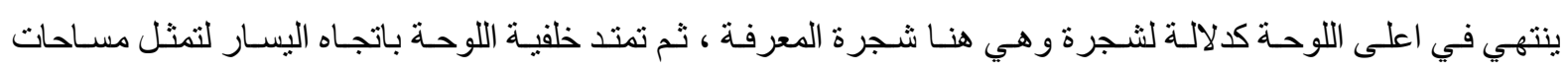

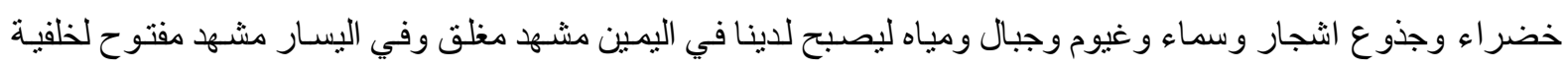

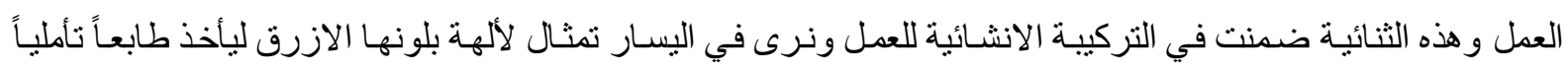

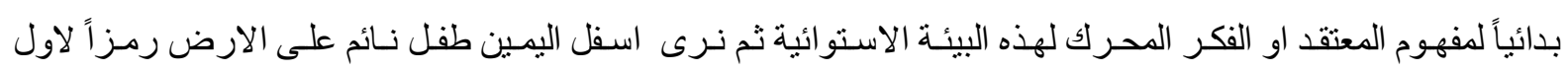

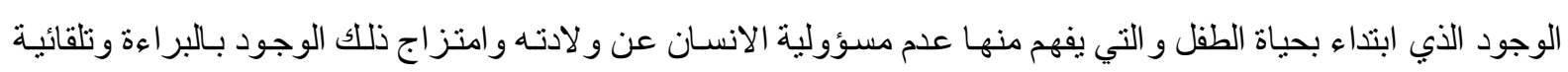
الحياة ثم نرى اعلى الطفل كلب بركض بعفويـة والى يسـار الطفل ثنلاث نسـاء بلامحهن الاستو ائية الاولى عاريـة بشكل

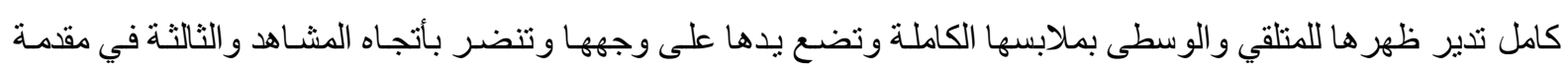

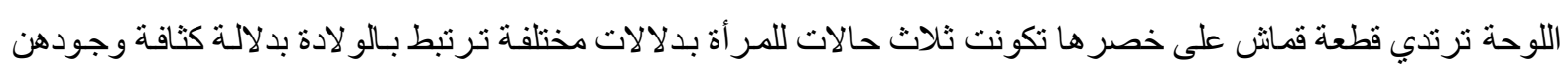

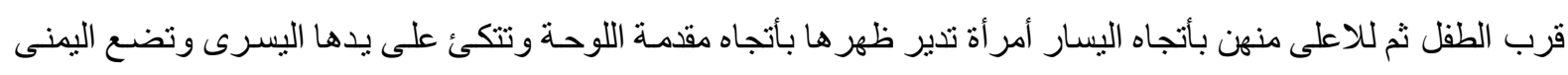

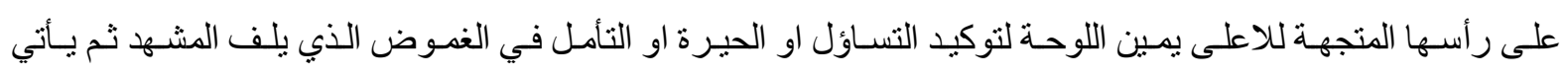
الرجل الذي يقف في اقل من منتصف اللوحة بأتجاه اليسـار وقد لامس حسافتي اللوحة العليا والسفلى بجسده العاري وقطعة القماش على خصره رمز اً للحياة البدائية الاستو ائية وهو يقطف التفاحة وقد تكون في معناهـا الباطن رمز أل لبداية الخطيئة

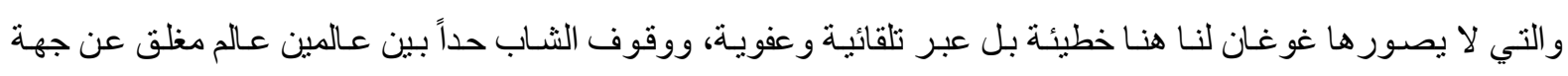

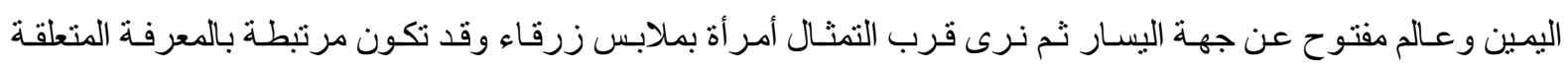

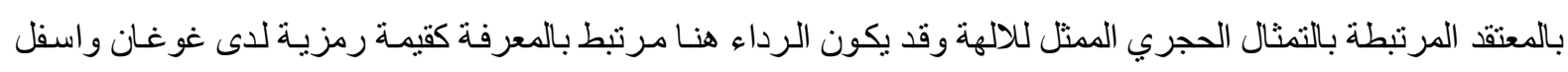

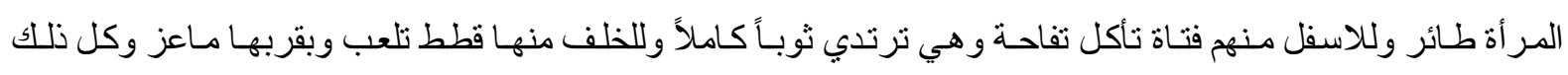

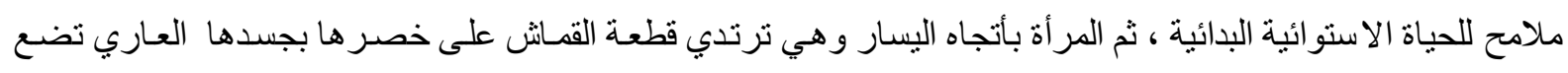

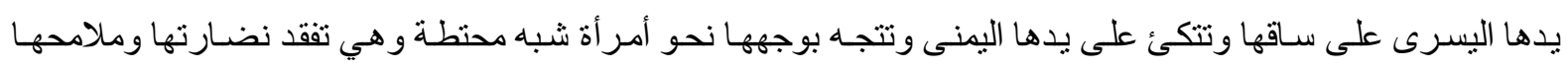
كأمر اءة عجوز دلالة على نهاية الحياة حيث تتحسس شكالها بخوف و توجس ، فلو نظرنسا للمشهـ بأكمله نرى آلية الحياة

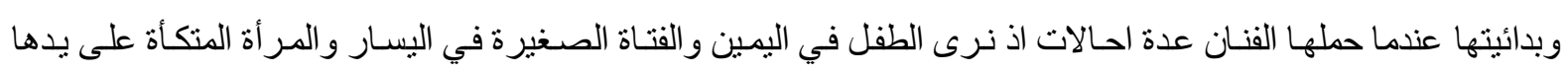

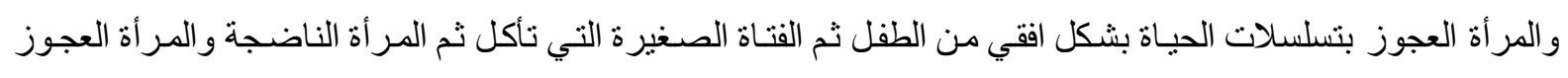

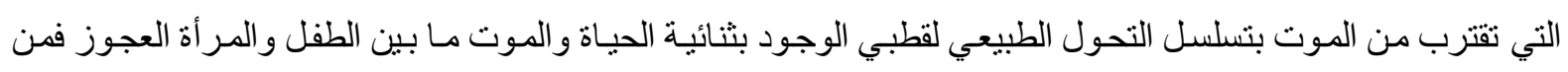

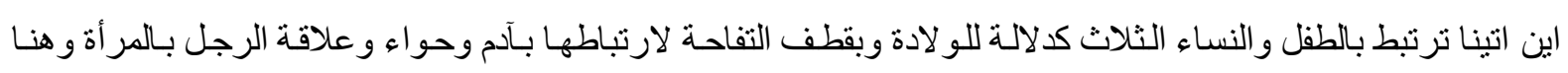

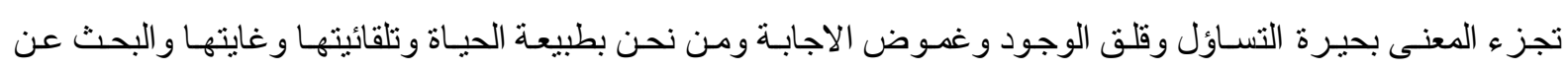


مسبباتها مـا بين تأمل وحيرة وبحث ومعتقد كمـا في التمثنال الحجري ، و الرجل و المر أة عند شجرة المعرفة لتوكيد ذلك

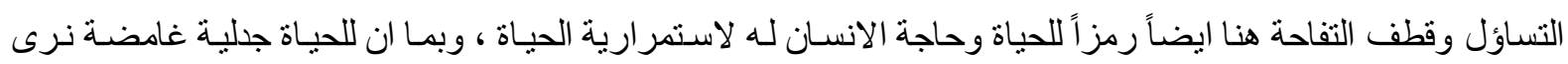

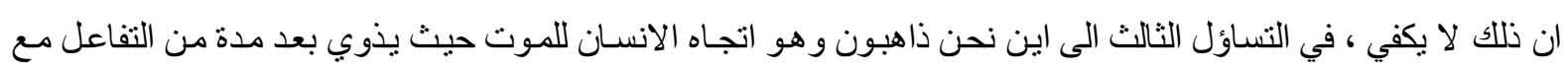

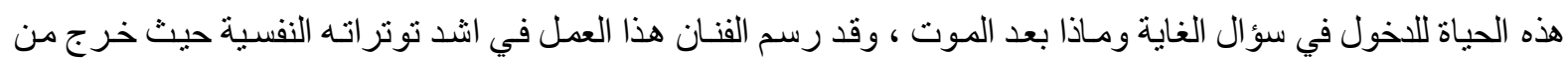

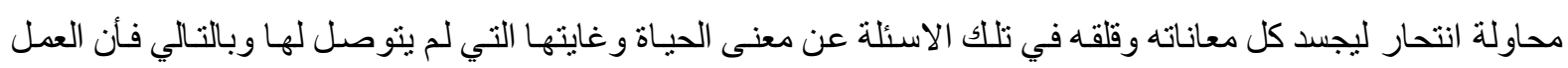
يوحي لنا بمعنى الحياة الغامض عبر قطبي الحياة والموت والزمن القابع بينهـا بكل مـا تحمله من بر اءة وجمـال وتلقائية

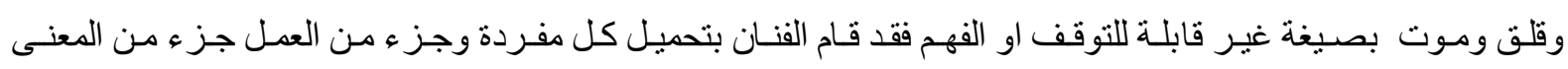
الإيحائي الكامن لتكون مرتكزات اساسية في اظهاره توظيف تلك الاجز اء او المفردات لبناء الدلالة الايحائية بعموميتها

لتوليد غموض يوازي قيمة الاسئلة بان يفصح عن نلك القلق المر افق لوجود الانسان بجدليته الغامضة المستمرة

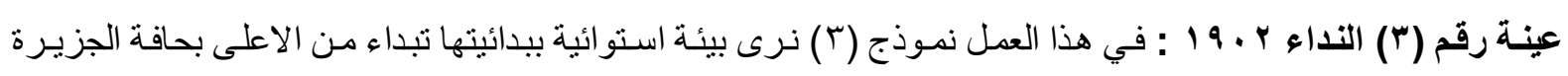

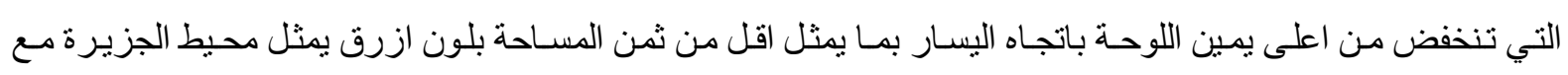
تفاصيل بعيدة ، ثم تليها مسـاحة صفراء منمثلـة منطقة مرتفعـة لتنخفض من مسـاحة تمثنل ثلث المسـاحة لحافـة اللوحسة

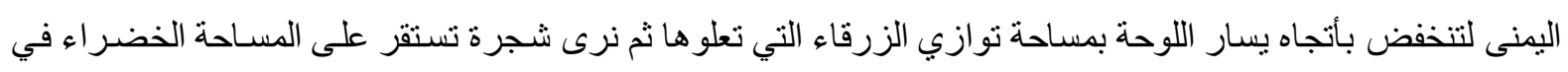

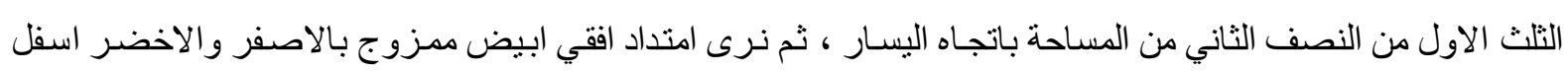

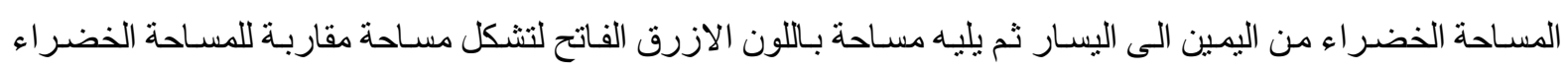

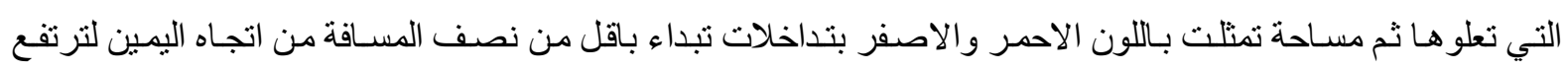

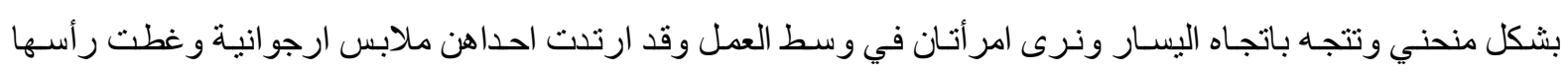

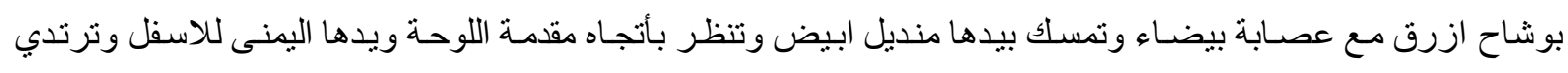

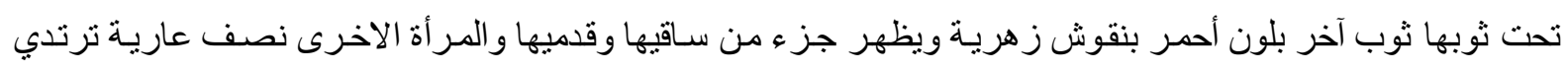

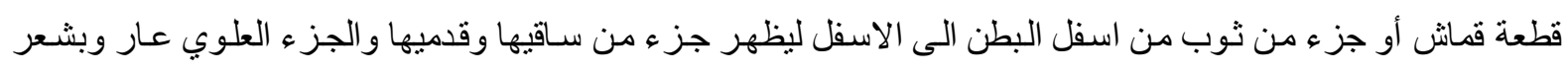

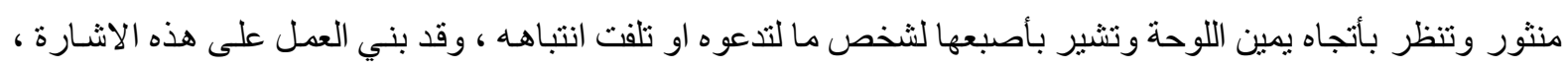

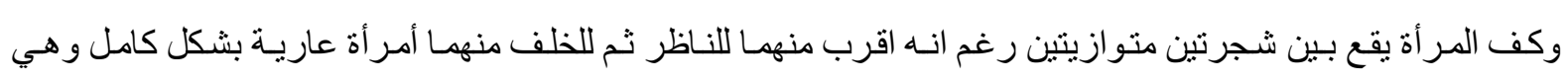

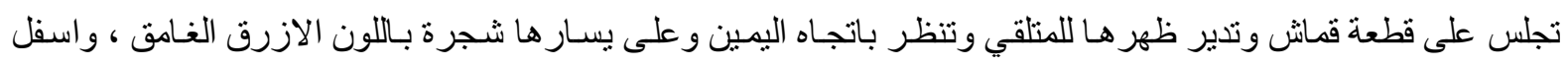

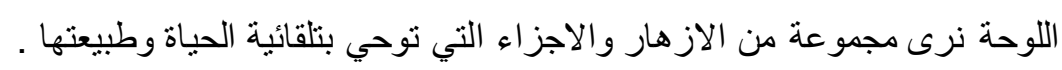

نرى في هذا العمل ان فكرة النسـاء الثناث و التي ترتدي احداهن ملابس كاملـة والاخرى نصف الملابس أي

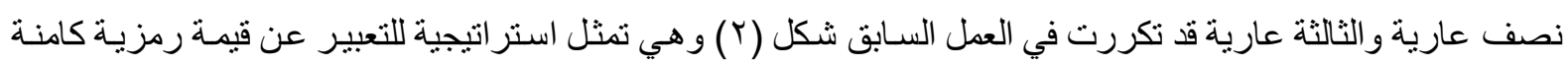

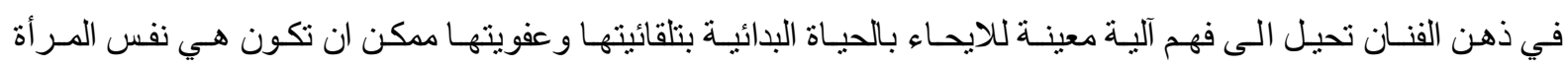

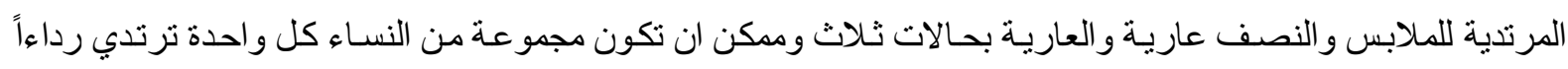
معيناً حسب عمر ها أو طبيعتها بلا قيود او فروض لتمثل التنوع في تلك الحياة بتلقائيتها ومـا هذه الاشـارة الا نداء للحياة

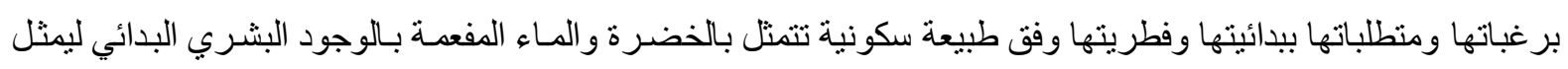

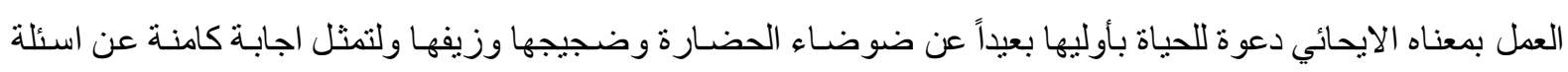
الفنان القلقة التي يحاول ان يوحي بها في اعمالـه اذ استطاع الفنان ان يوظف مفردات اللوحة بطريقة تحيل الى انهـ يكون 
المعنى الايحائي مرتبط بانــارة الاصبع للمر أة والتي يمكن للمتلقي ان يحتوي معناهـا او دلالتها وفق معطيات العمل بعد تهيئة اسباب المعنى على السطح الصوري .

\section{الفصل الرابع : نتائه البمث ومناقشتهـا}

اولا : نـنائج البـيث

ا ـ اعتماد آلية الايحاء بكلية العمل لا بجزئيته ممـا يجعل المفردات تسـاهم مسـاهمة جزئية لا تحقق دلالتها الا بكلية العمل

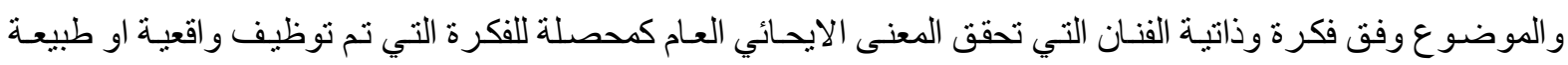

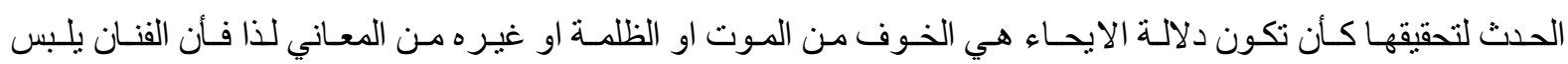

الموضو ع فكرته

r. استر اتيجية التوظيف الصوري التي يعتمدها الفنان تجعل ما هو كامن يطنى على بنية الصـورة من خـلال آليـة توظيف

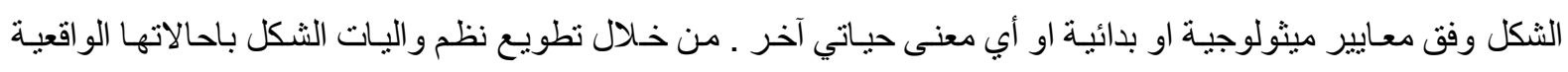

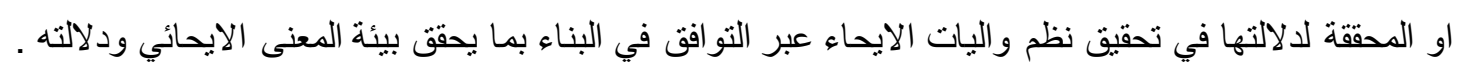

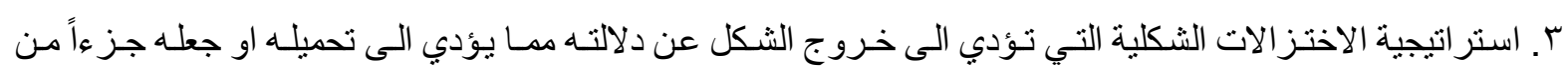

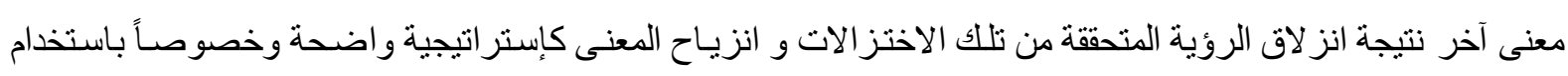

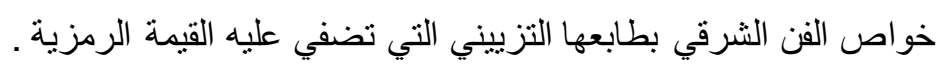
ع ـ تحميل الثكل لونـا غير مطابق لطبيعته مما يؤدي الى احالـة او سهولة احالته الى دلالـة اخرى او معنى اخر وهي

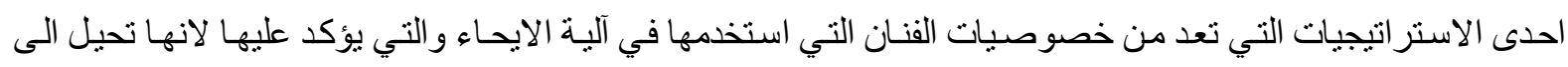
ماهو كامن ومضمر خلف الاشياء يمنح الاشكال قوة رمزية فاعلة .

○. تجزئة المعنى او الدلالة الايحائية من خلال تحميله للمفردات بتوظيف خصوصياتها الطبيعية وجعل بعض مرتكز اتها او اساسياتها نقاط تحول للمعنى الآخر او بناءه بطريقة تحيل الى ما هو مضمر وكامن ليطغى على المشهد . لئل

ثانبيا : الاستنـتاجات

ا ـ يستنتج الباحث ان الايحاء في العمل الفني لا يمكن تحقيقه بشكل مباشر او الاشـارة اليه بل تم بإضـافته او بنـاءه وفق استر اتيجية تتطلب فهم لماهبة المفردات وطريقة تفعيلها في بنية العمل الفني r . جعل البيئة الو اقعية بخصوصياتها منو افقة مع بيئة الفكرة التي يطرحها الفنان وفق ذاتيته يسهم بشكل فاعل باظهار

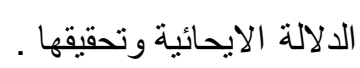
r. فهم آلية توظيف مفردات محددة وجطها هي المؤثر الرئيسي لتحقيق الاستجابة من قبل المتلقي يكون لها الاثر الفاعل

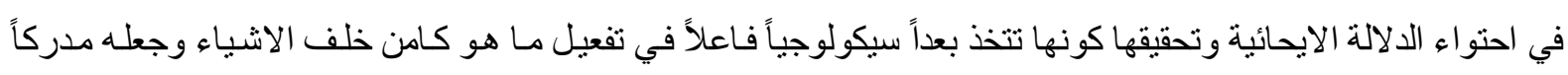
او ملموساً على سطح العمل .

ع. ذاتية الفنان تلعب دور رئيسي في تطويع المفردات وفرض اختزالات محددة لتحقيق المعنى الباطن

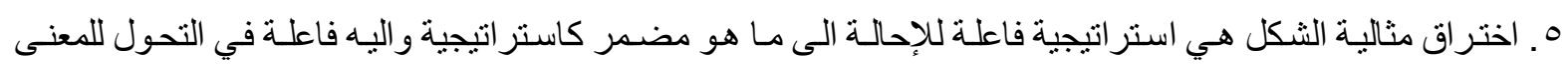
الاخر 
ثالثا : المقتترحات

ا ـ القيام بأعداد دراسات عن مفهوم الايحاء في المدراس الفنية حسب معايير ها الفنية الخاصة r. القيام بأعداد دراسات عن مفهوم الايحاء في المدارس الفنية المحلية

رابعا : التوصيات

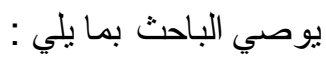
1 القيام بدراسة مكملة لموضوع البحث الحالي لفهم التحولات الفكرية في تحديد استراتيجية الايحاء والياته Y. دراسة المرتكزات و المعايير السيكولوجية واثرها في الية الايحاء

الهوامش

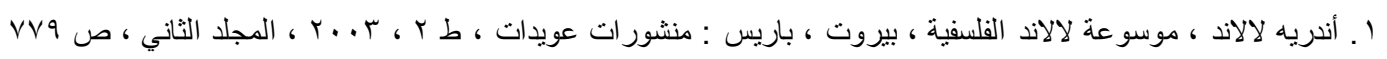

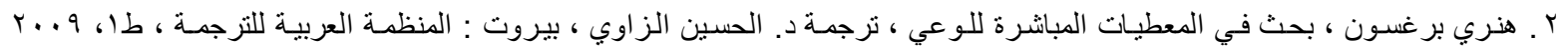

I Iص:

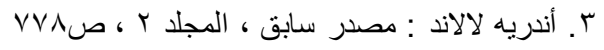

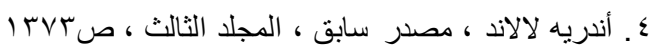

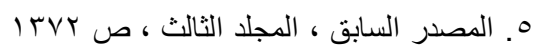

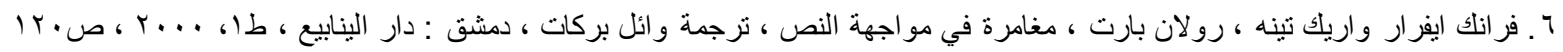

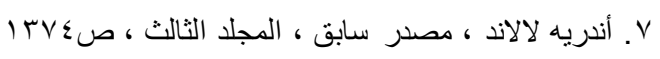

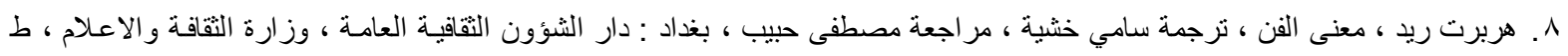

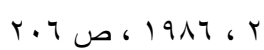

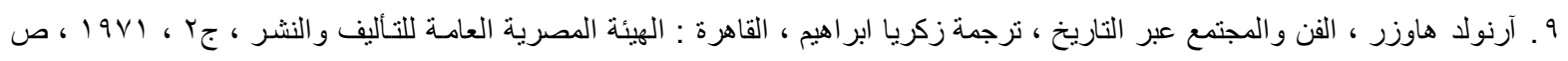

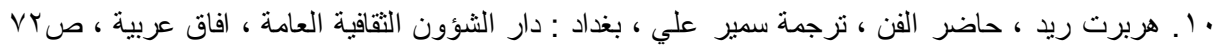

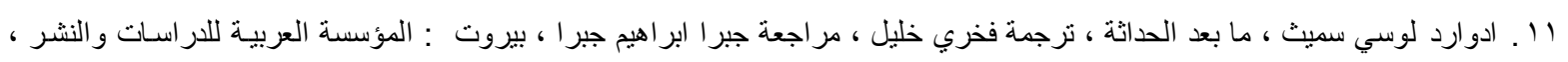

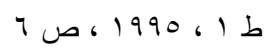

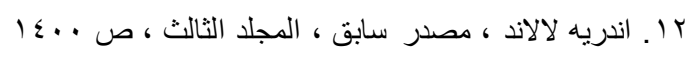

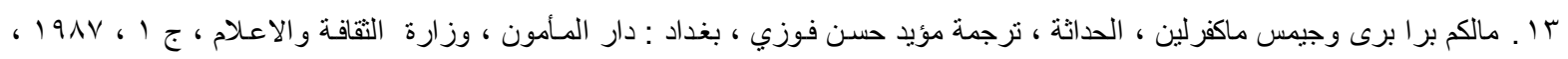

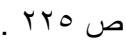
ع ا ـ آلان باونيس ، الفن الاوربي الحديث ، ترجمة فخري خليل ، مر اجعة جبرا ابر اهيم جبرا ، بغداد : دار المـأمون ، وزارة الثقافة والاعلام ، . 190 . 199. 10 ـ ـوزيف أميل مولر ، الفـن في القرن العشـرين ، ترجمـة مهاة فرج الخـوري ، مر اجعة عدنان البنـي ، دمشق: منشـورات وزارة الثقافة

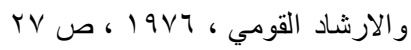

17 . . جي أي مولر ، فر انك ايلغرت ، مئة عام من الرسم الحديث ، ترجمة فخري خليل ، بغداد : دار المـأمون للترجمـة والنشر ، وزارة الثقافة

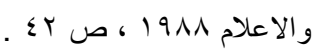

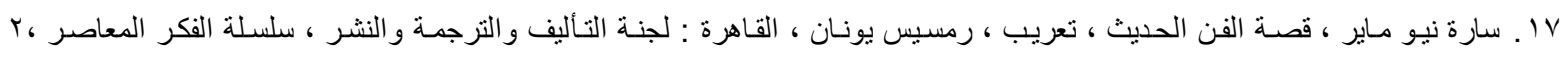

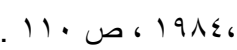

$\underline{\partial \operatorname{lon} \mid}$

ا ـ أميل مـولر ، جوزيف : الفن في القرن العشرين ، ترجمـة مهاة فرح الخوري ، مراجعة عدنان البني ، دمشق ، منشـورات وزارة الثقافة 


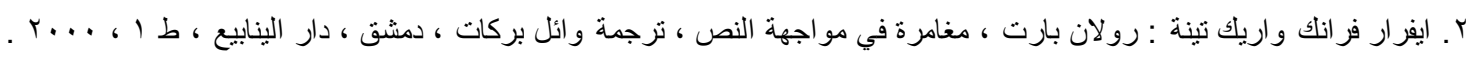

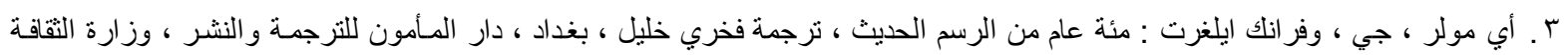

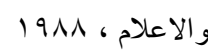

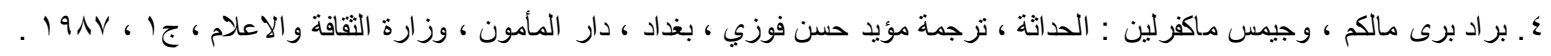

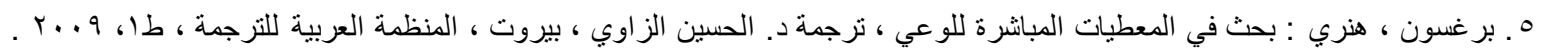

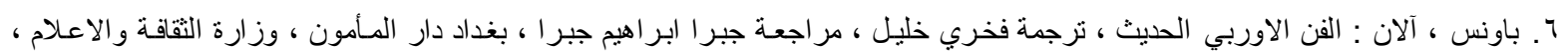

.199.

V. ريد هربرت ، حاضر الفن ، ترجمة سمير علي ، بغداد ، دار الثؤون الثقافية العامة ، افاق عربية .

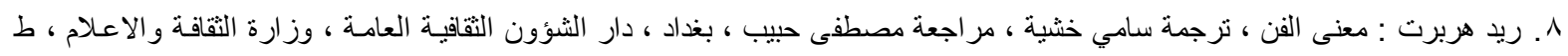
1917 ، 19

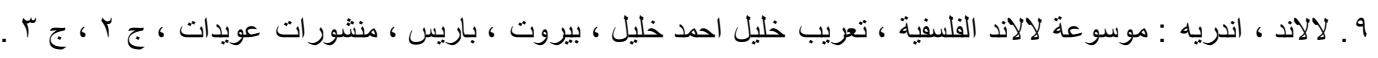

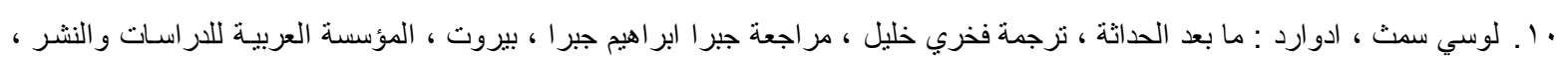
.1990 . 19

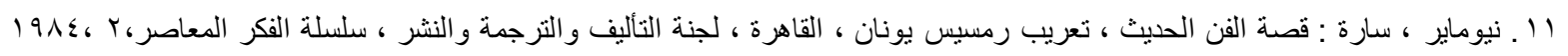

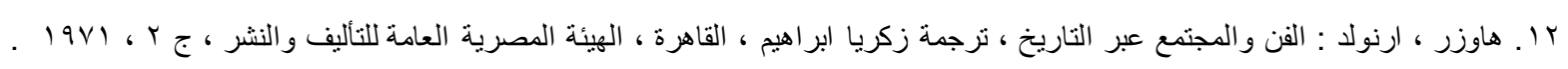

\section{( مجتمع البحث )}

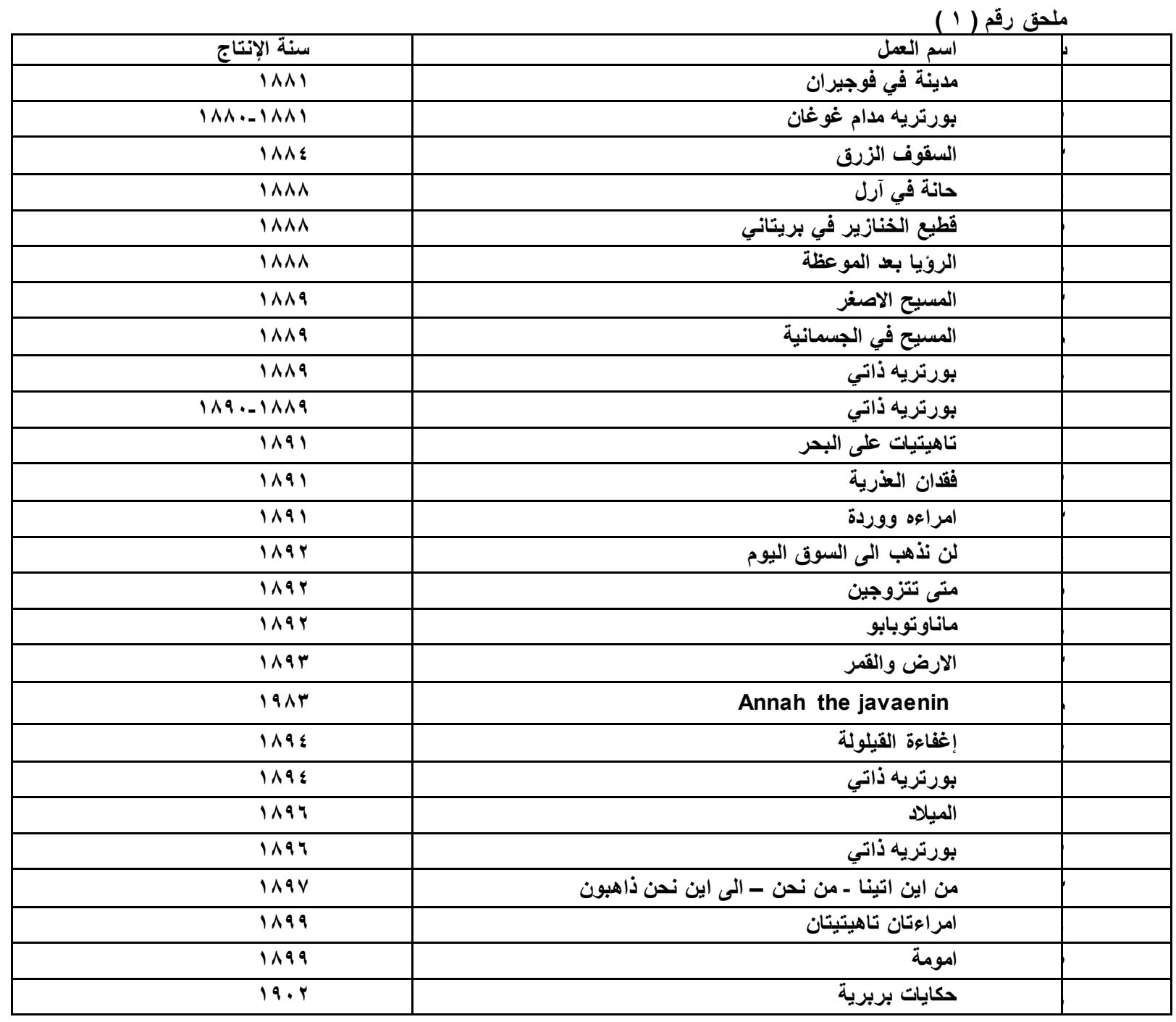




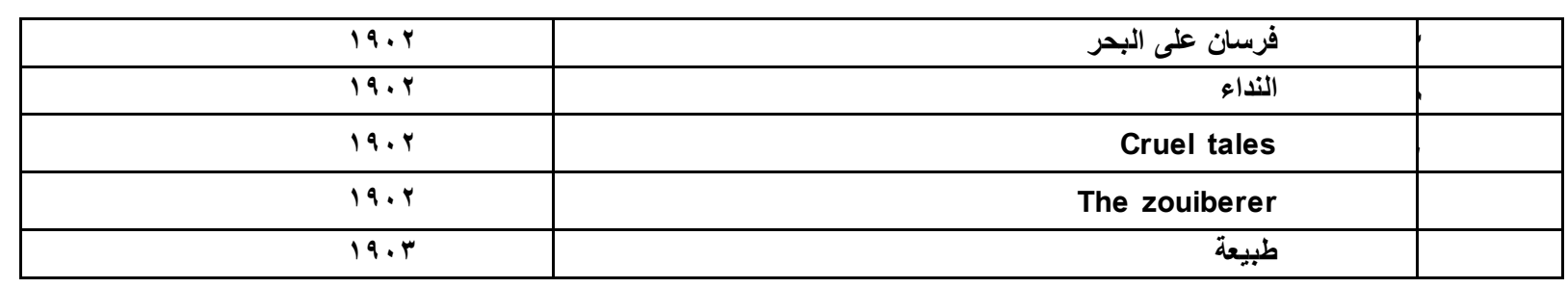

\section{قائمة عينـة البـصث}

\begin{tabular}{|c|c|c|c|c|c|}
\hline العائدية & الانتاجة & القياس & 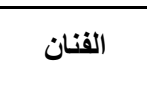 & الموضوع & ت \\
\hline معرض البرايت نوكس & 1194 & 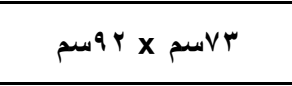 & بول غوغان & ماناو توبابو & .1 \\
\hline متحف الفنون الجميلة في & I^qV & 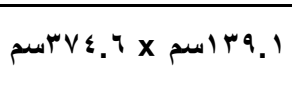 & بول غوغان & 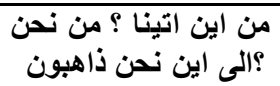 &.$r$ \\
\hline متحف الفن في كليف لاند & $19 . r$ & 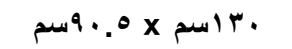 & بول غوغان & النداء & $r$ \\
\hline
\end{tabular}

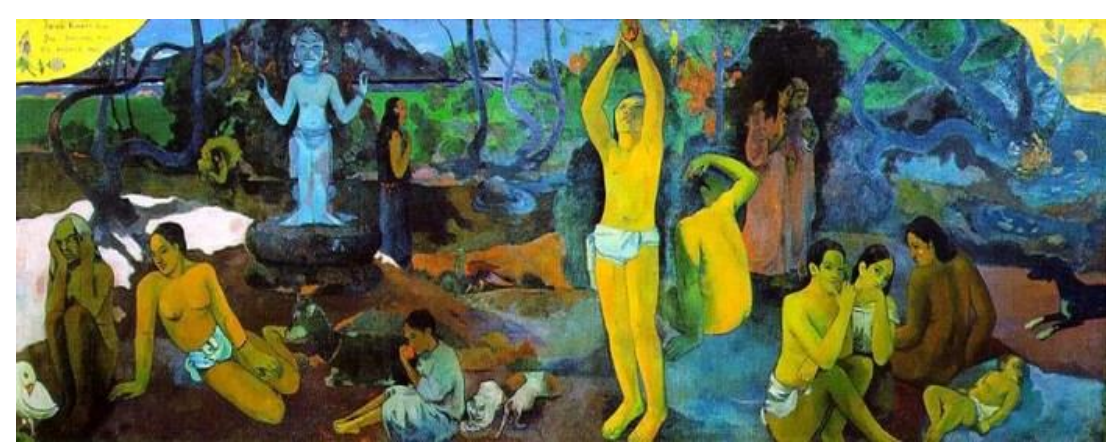

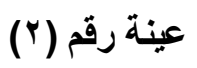

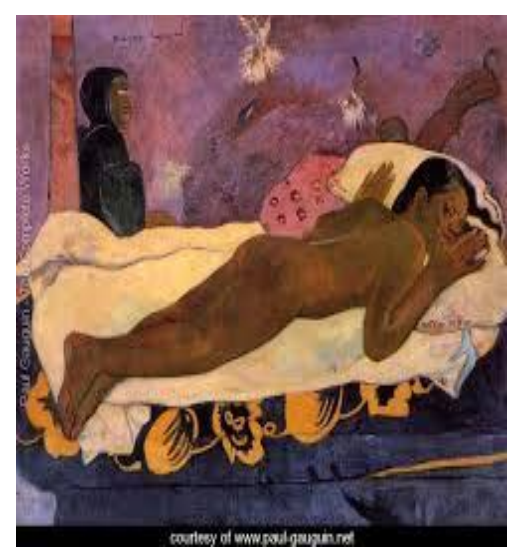

عينة رقم (1)

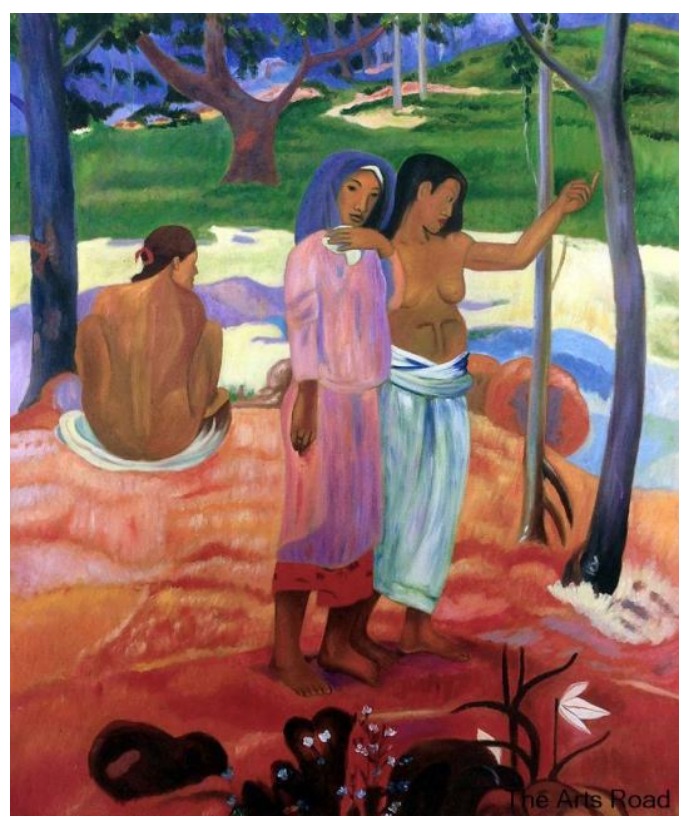

عينة رقم (r) 